\title{
The case of Ireland (1698) in context: William Molyneux and his critics
}

\begin{abstract}
William Molyneux's Case of Ireland (1698) is widely regarded as the most important work of Irish political thought published during the long eighteenth century. Over the last 40 years Patrick Kelly has analysed its arguments and patiently reconstructed the wider Anglo-Irish controversy of the late 1690 s in a series of illuminating articles. But in the wider historiography, anachronistic readings of Molyneux still persist, focused on his alleged contributions to evolving ideas of Irish nationhood. We can make better sense of the various strategies Molyneux adopted by situating him within the debates over the ancient constitution that took place in late seventeenth-century England. A careful reading of the hostile responses to Molyneux also reveals that the Case of Ireland prompted the first attempt by English constitutional writers to conceptualise their empire as a single power structure. Contextualising Molyneux in this way prompts further methodological questions concerning the indifference among most Irish scholars to the 'Cambridge school' of intellectual history.

[158 words]
\end{abstract}

End of abstract

Introduction 
William Molyneux's Case of Ireland is widely regarded as the most important and influential work of Irish political thought published during the long eighteenth century. Historians have described its significance in two principal ways. The most common focuses on Molyneux's rejection of English claims that Ireland was a colony. By insisting that Ireland was rather 'a Compleat Kingdom within it self', possessing its own autonomous parliament and law courts and stretching back to the reign of Henry II, Molyneux has been taken to exemplify the deepening sense of Irishness allegedly felt by the Protestant elite following the defeat of their Catholic counterparts at the Boyne and Aughrim. ${ }^{1}$ The case of Ireland therefore belongs to the pre-history of Irish nationalism. Another widespread assumption is that Molyneux's appeal to natural rights, and in particular to John Locke's Two treatises (1689), forms the central thrust of this compendious work. On this reading he provided the essential tools for later generations of patriots to construct a democratic, non-sectarian vision of the Irish nation. Neither of these views represents an accurate account of the text taken as a whole; nor do they bear much relation to the way that Molyneux was read by his contemporary critics.

The primary significance of Molyneux's Case of Ireland lies in its elaboration of an Irish variant of the ancient constitution. Its arguments are best approached via J. G. A. Pocock's classic work Ancient constitution and the feudal law (1957), which argued that many political debates in seventeenth-century England were conducted 'by appeal[ing] not directly to abstract political concepts, but to the existing "municipal" laws of the country concerned and to the concepts of custom, prescription and authority which underlay

\footnotetext{
${ }^{1}$ William Molyneux, The case of Ireland's being bound by acts of parliament in England, stated (Dublin, 1698), 148. In addition to various examples cited below, Molyneux's Irishness is emphasised by D. G. Boyce, Nationalism in Ireland ( $2^{\text {nd }}$ edn., London, 1991), 102-07
} 
them'. ${ }^{2}$ The point can be illustrated by quoting the Tory historian and propagandist Robert Brady, the pivotal figure in Pocock's book, who warned in 1681 that the 'Turbulent Men' who preached up 'the Liberty of the People' came in two distinct varieties. The first were those who taught that political power originated with the people, and that kings could therefore be deposed by them. This was the tradition of resistance theory that culminated in Locke's Second treatise, written around the same time but not published until 1689 . The other type of trouble-makers were those who sought to demonstrate from 'Ancient Rights and Privileges' that England was a kind of elective monarchy. It was the second group that occupied the ideological mainstream at the time of the Exclusion crisis and the Revolution of 1688. Their most influential spokesman was William Petyt, author of The Antient right of the commons of England asserted (1680). Locke's avoidance of the ancient constitution in favour of natural-rights theory made him almost unique. The initial impact of the Two treatises was consequently very limited. But Pocock noted that James Tyrrell's vast Bibliotheca politica (1694) served up Petyt with a smattering of Locke; and, as he added all the way back in 1957, the same could be said of William Molyneux's Case of Ireland. ${ }^{3}$ To attempt to connect Molyneux to the ancient constitutionalism of writers such as Petyt is hardly, in itself, a revolutionary suggestion. Specialists have certainly appreciated the fundamental importance of legal and historical arguments in the Case of Ireland. The outstanding example is Patrick Kelly, who has patiently reconstructed the Anglo-Irish controversy of the late 1690 s in a series of illuminating articles published since $1979 .{ }^{4}$ But it

\footnotetext{
2 J.G.A. Pocock, The ancient constitution and the feudal law: a study of English historical thought in the seventeenth Century ( $2^{\text {nd }}$ edn., Cambridge, 1987), 17.

${ }^{3}$ Pocock, Ancient constitution, 188, 238.

${ }^{4}$ This article builds upon Kelly's pioneering research; see, in particular, Patrick Kelly, 'Recasting a tradition: William Molyneux and the sources of The case of Ireland... stated (1698)', in Jane H. Ohlmeyer (ed.), Political
} 
is nevertheless fair to say that most accounts have concentrated on Molyneux's relationship with Locke or on the schizophrenic Irishness of the Williamite Protestants. It is worth recalling that the original title of Molyneux's Case was 'An humble remonstrance to the parliam $^{t}$ of England in relation to Ireland', and it was written with the intention of correcting misrepresentations of Irish affairs in London. ${ }^{5}$ The three authorities cited most frequently by Molyneux were the great English legal scholars Sir Edward Coke (1552-1634), John Selden (1584-1654) and William Prynne (1600-1669); other important reference points included the medieval chronicler Matthew Paris and the antiquarian Sir Henry Spelman (1563/4-1641), as well as Petyt himself, the leading whig theorist of the Restoration. The basic contention of the following article is that Irish historians have still to investigate fully the intellectual context for the composition of Molyneux's work. In particular, English reactions to the Case of Ireland have never been systematically analysed, although they provide the most valuable clues we have in establishing how Molyneux was understood by his contemporaries. In the first section below, the contents of the Case of Ireland are summarised, and Molyneux's protest is compared with other 'patriot' writings in order to highlight its distinctive features. The main body of the article then develops two more specific claims. The first is that the best way of making sense of the various strategies adopted by Molyneux is to study the conventions of English constitutional writing of the late

thought in seventeenth-century Ireland: kingdom or colony (Cambridge, 2000), 83-106; and 'Conquest versus consent as the basis of the English title to Ireland in William Molyneux's Case of Ireland ... stated (1698)', in Ciarán Brady and Jane H. Ohlmeyer, (ed.), British interventions in early modern Ireland (Cambridge, 2005), 33456.

${ }^{5}$ P. H. Kelly, 'The printer's copy of the MS of William Molyneux, "The case of Ireland's being bound by acts of parliament in England, stated" 1698', Long Room, 18-19 (Spring/Autumn 1979), 13 
seventeenth century. Particular attention is paid to Molyneux's notorious dismissal of the native Irish population as irrelevant to any discussion of the rights of the 'people of Ireland'. The other claim made here is that the English reception of the Case of Ireland illuminates a broader topic, the ideological origins of the British empire. As far back as the 1670s, it had been claimed that Ireland was one of the chiefest Members of the British Empire' ${ }^{6}$ But the terminology of empire was not a salient feature of English political discourse, and, as one major treatment affirms, 'there was little concentrated thought on the nature of imperial sovereignty and colonial obligation'.7 'Empire' had famously been attributed to England during the Henrician Reformation, meaning that the kingdom possessed sovereignty over itself in matters both temporal and spiritual. ${ }^{8}$ This sense of the word still echoed during the reigns of William and Anne, when Scottish writers boasted that they, as much as the English, could boast of an 'imperial crown'. ${ }^{9}$ Alternatively, the word was used vaguely to imply either territorial extent or conspicuous magnificence. After the union of crowns in 1603, the monarchy of the Stuarts was sometimes described as imperial by its eulogists. In the 1690s, however, the concept of empire - this time English rather than British - generally signified the projection of England's power overseas, or rather on the seas. It gained currency among poets rather than political theorists, and although its connotations included colonial

\footnotetext{
${ }^{6}$ The present state of Ireland: together with some remarques upon the antient state thereof (London, 1673), A2 ${ }^{\mathrm{V}}$ $\mathrm{A} 3^{\mathrm{r}}$.

7 Peter N. Miller, Defining the common good: empire, religion and philosophy in eighteenth-century Britain (Cambridge, 1994), 160.

8 John Robertson, 'Empire and union: two concepts of the early modern European political order', in John Robertson (ed.), A union for empire: political thought and the British union of 1707 (Cambridge, 1995), 3-36; J. G. A. Pocock, 'Political thought in the English-speaking Atlantic, 1760-1790', in J. G. A. Pocock (ed.), The varieties of British political thought, 1500-1800 (Cambridge, 1993), 257, 259.

${ }^{9}$ William Ferguson, 'Imperial crowns: a neglected facet of the background to the Treaty of Union of 1707', Scottish Historical Review, 53 (1974), 22-44.
} 
expansion and colonial trade its chief signification was maritime strength. Simultaneously, the settlements across the Atlantic came to be described as 'the English empire in America', although they were more frequently known as 'the plantations', and the body which administered them, and upon which Locke sat between 1696 and 1700, as the Board of Trade and Plantations. Molyneux's Case of Ireland seems to have prompted the first attempt by English writers to conceptualise their empire as a single power structure encompassing both European kingdoms and transatlantic colonies.

This contextualised reading is indebted not only to Pocock's Ancient constitution and the feudal law but also to Peter Laslett's classic edition of Locke's Two treatises of government, by far the best-selling of all the canonical works in the 'Cambridge Texts in the History of Political Thought', which carefully recorded Molyneux's borrowings from Locke. ${ }^{10}$ These two works have been justly celebrated, not just as decisive turning-points in seventeenthcentury English historiography, but as the foundations of a collective enterprise, the socalled Cambridge school of intellectual history, best known for its early methodological manifestos, and above all for Quentin Skinner's famous article 'Meaning and understanding in the history of ideas' (1969). ${ }^{11}$ The conclusion of the present article recasts its central argument in a more explicitly methodological form, underlining the enduring value of the 'Cambridge' approach.

\footnotetext{
${ }^{10}$ Average paperback sales for the student edition of Laslett between 1988 and 2008 were on average 7,500 annually: Richard Fisher, 'How to do things with books': Quentin Skinner and the dissemination of ideas', History of European Ideas, 35 (2009) 279.

${ }^{11}$ Skinner's article first appeared in History and Theory, 8 (1969) and was revised for his Visions of politics, volume I, 57-89. The connections between Laslett, Pocock and Skinner are recorded in J. G. A. Pocock, 'Quentin Skinner: the history of politics and the politics of history', in Pocock, Political thought and history: essays on theory and method (Cambridge, 2009), 123-42, and in many of the essays in Brett et al., Rethinking the foundations, note 105 below.
} 
The Case of Ireland

Molyneux's Case of Ireland was written at speed in the early months of 1698. Its immediate context was the campaign by leading Irish politicians to obstruct the passage of a bill at Westminster restricting the export of Irish woollens. ${ }^{12}$ In Ireland itself the most belligerent opponent of English interference was William King, then bishop of Derry, who agitated in vain for the grand juries to draw up addresses in defence of Ireland's woollen manufacture. Over and over again in his correspondence King repeated the variations on the patriotic formula later popularised in Swift's Drapier's Letters: 'if I can be taxed \& bound by laws to which I am no party; I shall reckon myself as much a Slave, as one of the grand seignours mutes' ${ }^{13}$ King had also immersed himself in a longstanding legal dispute between the bishopric of Derry and the Honourable the Irish Society of London which, in the autumn of 1697 , had escalated into a clash between the English and Irish lords, both claiming to be the supreme court of appeal in Irish cases. In London, King's case was pressed by his lawyer James Sloane and his agent Francis Annesley, who insisted that the rights of the Irish lords derived from 'the Constitution of that Kingdom, by the Concessions and Grants of the Kings of England, and from Usage and Prescription'. ${ }^{14}$ Their arguments relied heavily on precedents derived from Coke, Prynne and Selden. King's efforts to distance himself from the Case of Ireland, following its condemnation by the English house of commons, have obscured his close relationship with its author. Both had been members of the Dublin

\footnotetext{
${ }^{12}$ For the constitutional issues, see C. I. McGrath, Ireland and empire, 1692-1770 (London, 2012), 37-50.

${ }^{13}$ King to [Bishop Thomas Lindsay], 13 May 1698, Trinity College Dublin [hereafter TCD] MS 750/1/229.

${ }^{14}$ James Sloane and Francis Annesley, The Lord Bishop of Londonderry's case (London, 1698), 2.
} 
Philosophical Society before the revolution; both had collected parliamentary precedents in connection with the Derry case; in July 1698 King was waiting for a chastened Molyneux to join him in Bath. ${ }^{15}$

During the 1690s Westminster politicians interfered in Irish affairs in various ways - by pressing for the 'resumption' of the estates forfeited by Jacobite landowners and distributed to his favourites by William III, by asserting the appellate jurisdiction of the English house of lords over Irish lawsuits, and by drafting legislation to restrict the competition from Irish manufactures. In London it seemed outrageous that a community of Irish Protestants that originated in England and had been rescued from disaster by English money and arms twice within half a century should compete with the commerce and manufactures of the mother country. Proposals to prohibit the import of Irish woollens to England, sometimes coupled with compensatory schemes to promote the manufacture of linen in Ireland, had emanated from the manufacturers of the west country as far back as the 1660s. The campaign gained momentum, however, with the publication of An essay on the state of England in relation to its trade (1695) by the Bristol merchant and MP John Cary, and with the economic crisis of 1696-7. ${ }^{16}$ Cary's argument was that Ireland was a plantation or colony of England, and its trade must be directed to the profit of the mother country. Among other considerations, securing Ireland's commercial subordination to England would go some distance to recompense 'the vast Charges we have been at for its Reduction and Delivery out of the

\footnotetext{
${ }^{15}$ King to Annesley, 16 July 1698, TCD 750/1/248.

${ }^{16}$ Patrick Kelly, 'The Irish woollen export prohibition act of 1699: Kearney re-visited', IESH, 7 (1980), 22-43.
} 
Hands of foreign Powers and Popish Cut-throats, and that not less than twice in Forty Years'.$^{17}$

Agitation against Irish woollens resumed in December 1697 with a petition to the English commons from the merchants of Exeter and the simultaneous appearance of a short, abrasive, anti-Irish tract entitled $A$ letter from a gentleman in the country. The pamphlet was sponsored by the 'Country' opposition in the English parliament and almost certainly written by John Toland, then involved in the opposition campaign against standing armies. ${ }^{18}$ His case was partly economic, concentrating on the natural resources, favourable climate, cheaper labour and geographical advantages which allegedly made Ireland such a dangerous rival. But Toland also sought to discredit the Protestant Irish by suggesting that their experience as a minority, encircled by hostile population, had engendered a despotic mentality, injurious to the liberties of England. Mindful, perhaps, of the condemnation of his book Christianity not mysterious (1696) by the Irish commons, Toland mischievously complained that the Irish were suffered to 'hold Parliaments, settle Estates, pass Attainders, Regulate our Trade, Pardon their own Rebellions, that we have paid for' ${ }^{19}$

The Protestants of Ireland were horrified. They had suffered, most famously in 1641 but also in 1688. As one angry critic put it, the 'Brittish of Ireland, who are Proprietors of most of that Kingdom, were as one man in the interest of England'; they had resisted the tyranny of James II until delivered 'from the Ravage[s] and Murders of the Rebellious Irish' by

\footnotetext{
${ }^{17}$ John Cary, A discourse concerning the trade of Ireland and Scotland, as they stand in competition with the trade of England (Bristol, 1695, London, 1696), 5-6.

${ }^{18}$ Reprinted in Patrick Kelly, 'A pamphlet attributed to John Toland and an unpublished reply by Archbishop William King', Topoi, vol. 4, no. 1 (1985), 81-90.

19 [John Toland], A letter from a gentleman in the country, to a member of the house of commons, in reference to the votes of the $14^{\text {th }}$ instant (n. pl., n.d.), 3. The author recommends Cary's Discourse on p. 4.
} 
William. ${ }^{20}$ This was apparently Sir Francis Brewster, merchant, MP and the author of Essays on trade and navigation (1695). Brewster explained that the inhabitants of Ireland had their own constitution based on 'a Compact that they should hold Parliaments, with the same Priviledges as England', although he concentrated mostly on questions of trade and manufactures. ${ }^{21}$ Responses to Toland generally made two economic arguments. The first was that Ireland's prosperity directly benefited England. The profits of Ireland's trade ultimately found their way to London, in the form of the rents paid to absentee landlords, or the expenses paid for the education of gentlemen from Ireland at Oxford, Cambridge, or the Inns of Court, or on the purchase of 'vast Quantities of Hops, Tobacco, Sugar, Dye-Stuffs, and a thousand other things'. In this respect, as the otherwise unknown John Hovell optimistically suggested, Ireland was no more foreign than Yorkshire. ${ }^{22}$

Patriotic writers also protested that English observers failed to distinguish properly between the three ethnic communities that inhabited the island of Ireland. Patriotic writers spoke on behalf of those who were called 'the English of Ireland', 'the English Irish' or, less frequently, the 'Brittish of Ireland'. ${ }^{23}$ The ties of blood between the two communities were frequently emphasised. Francis Annesley explained that the Protestants of Ireland consisted of 'Englishmen sent over to conquer Ireland, your Countrymen, your Brothers, your Sons, your Relations, your Acquaintance, governed by the same King, the same Laws; of the same

\footnotetext{
${ }^{20}$ An answer to a letter from a gentleman in the country, to a member of the house of commons: on the votes of the $14^{\text {th }}$ instant (London, repr. Dublin, 1698), 9.

${ }^{21}$ An answer to a letter from a gentleman in the country, 8.

${ }^{22}$ [John Hovell], A discourse on the woollen manufactury of Ireland and the consequences of prohibiting its exportation (Dublin, 1698), 11.

${ }^{23}$ Patrick Kelly, 'Pamphlet attributed to John Toland', 87; The substance of the arguments for and against the bill, for prohibiting the exportation of woollen manufacture from Ireland to forreign parts (London, 1698), 1-2; Answer to a Letter from a gentleman in the country, 9.
} 
Religion; and in the same Interest, and equally engaged in the same cause of Liberty'. ${ }^{24}$

Hovell reminded his readers that they were the same people, scattered on either side of the Irish Sea, sharing the same religion: 'we are a Province of their Empire' ${ }^{25}$ Brewster divided the Irish into three categories, the 'Irish Papists' who were hell-bent on the extirpation of their heretical enemies, the 'Scotch Dissenters or Presbyterians' of the north, whose kinsmen had so recently turned the Episcopal clergy of out of their livings in Scotland, and finally 'the English of Ireland' ${ }^{26}$ It was the last group, the Irish patriots urged, who were concerned in the Woollen Manufacture. ${ }^{27}$ Since papists were largely excluded from towns, the clothiers, combers, spinners and weavers, dyers, rackers and pressers who would suffer as a result of England's interference were all exclusively or at least predominately Protestant. The 'Scotch' were just as loathsome, and perhaps more dangerous, than the Catholic Irish, given the flourishing of the linen manufacture in the north. ${ }^{28}$

In contrast, Molyneux's Case of Ireland placed little emphasis on ethnic ties between England and Ireland and made no reference to political economy. Molyneux chose instead to address the wider issue of legislative independence within the British multiple kingdom. It was this approach that made his work so relevant to American as well as Irish patriots in the 1760s. Molyneux set out to demolish three arguments that were employed to justify

\footnotetext{
24 [Francis Annesley], Some thoughts on the bill depending before the right honourable the house of lords, for prohibiting the exportation of the woollen manufactures of Ireland to foreign parts (Dublin, 1698), 16. For the attribution to Annesley, see Kelly, 'Kearney re-visited', IESH, 35, n. 47.

${ }^{25}$ [Hovell], Discourse on the woollen manufactury, 10.

${ }^{26}$ [Francis Brewster], A discourse concerning Ireland and the different interests thereof, in answer to the Exon and Barnstaple petitions (London, 1698), 13, 23, 34-5, 44.

${ }^{27}$ Substance of the arguments for and against the bill, 1-2.

28 [Brewster], Discourse concerning Ireland, 33-5, 44; Kelly, 'Pamphlet attributed to John Toland', 88. [Hovell], Discourse on the woollen manufactury, 18.
} 
England's legislative power over Ireland - those founded on conquest, precedent and purchase. One by one, he sought to close off the various routes open to advocates of English legislative supremacy. First, he examined the moment at which Ireland became annexed to the English crown, following the expedition of Henry II in 1172. Drawing on the standard account by Giraldus Cambrensis, and on later medieval chroniclers (Roger de Hoveden, Matthew Paris, John Brampton), he aimed to establish that the capitulation of the native Irish princes to Henry II should be regarded as a 'Voluntary Submission of all the Ecclesiastical and Civil States of Ireland' without recourse to arms. ${ }^{29}$ This enabled him to distinguish, as Spelman's Glossarium (1626) had done, between two meanings of the word conquestus, which could signify a peaceable acquisition as well as a violent subjugation. ${ }^{30}$ Indeed, as he added very unwisely, 'England may be said much more properly to be Conquer'd by William the First, than Ireland by Henry the Second' ${ }^{31}$

But supposing Ireland had been conquered, Molyneux continued, what rights might legitimately follow from this fact? His answer, running over ten pages, was taken almost word-for-word from chapter sixteen of 'an Incomparable Treatise concerning the True Original, Extent and end of Civil Government' rumoured to have been written by 'my Excellent Friend, JOHN LOCKE' ${ }^{32}$ This section marked an abrupt change of gear. Until this point Molyneux's pamphlet largely followed the earlier constitutional arguments of Sir Richard Bolton and Sir William Domville. Now he turned to the very different mode of

\footnotetext{
${ }^{29}$ Molyneux, Case of Ireland, 13.

${ }^{30}$ Case of Ireland, 12.

${ }^{31}$ Case of Ireland, 14.

${ }^{32}$ Case of Ireland, 26-7. Molyneux was the first to identity publicly the author of the Two treatises. See Patick Kelly, 'Locke and Molyneux: the anatomy of a friendship', Hermathena, no. 126 (Summer 1979), 38-54.
} 
argument of the Second treatise, and tracked Locke just as closely. To begin with, Molyneux explained that even a just conqueror acquires no power over his own forces - those, that is, who had fought with him; secondly he gains no power over non-combatants, but only over those who took up the sword against him; and thirdly the rights of conquest extend neither to the property of the defeated party, beyond the natural compensation due to the victor to cover the costs of his campaign, nor to their descendants.

This brisk analysis of the historical and philosophical aspects of conquest occupies fewer than thirty pages of the total 174 . The bulk of his treatise is devoted to the history of Irish legislation, starting with a long discussion of how English government and the common law had been transplanted to Ireland in the first place. Molyneux began with Matthew Paris's account of the first 'public assembly and council' of the Irish at Lismore summoned before Henry's departure, which introduced the liberty of holding parliaments 'as a separate and distinct Kingdom from England'. ${ }^{33}$ By putting the Irish on the same legal and constitutional footing as the English, the Lismore assembly provided an clearly attested example of an 'Original Compact between a King and People', exactly the same principle invoked so frequently in English debates over the Glorious Revolution. ${ }^{34}$ This royal grant was confirmed by the Irish Modus, the authenticity of which, as Molyneux admitted, had been questioned by Selden and Prynne; but Ireland's status as a distinct kingdom had also been recognised by John and by Henry III, who had granted Ireland its Magna Carta in November 1216. Molyneux now came to the lengthiest section of his work, an examination of a series of

\footnotetext{
${ }^{33}$ Case of Ireland, 29.

${ }^{34}$ Case of Ireland, 37-8.
} 
English statutes which had been offered as precedents for the legislative authority of Westminster in Irish affairs, running from the thirteenth century to the Restoration.

Finally, Molyneux briefly considered the possibility that England's title to Ireland could be derived from 'purchase' - that is, from the large sums of money England had spent in subduing the stubborn Irish. We have seen already that the financial cost of securing Ireland was a major theme of English propaganda. Not unreasonably, Molyneux retorted that in suppressing Irish insurrections England was acting in its own self-interest. In passing, he carefully distinguished domestic rebellions or 'Intestine Commotions', such as the various risings of Irish papists, from cases of international warfare..$^{35}$ Much earlier, Molyneux had discounted the idea that the Catholic rebellions extinguished by the English could have conferred rights of conquest upon the victors. After all, he protested, there had been frequent rebellions in England too - such as the Wars of the Roses or the Civil Wars of the 1640 s. $^{36}$ The bloody insurrections of the Irish and the implacable hatred which apparently fuelled them were of course a major theme of much writing on Irish matters, too infamous for Molyneux to ignore. But in a 'settled Commonwealth', he observed, rebellious subjects might forfeit their estates as well as their lives, depending on the municipal laws of the kingdom. It was not unjust that subjects must submit to such 'constitutions' since these were vital regulations for preserving property to which they or their ancestors had consented. ${ }^{37}$ Molyneux thus contrived to ratify the dispossession of Gaels and the Old English whilst protecting his core position that the submission of the Gaelic chieftains to

\footnotetext{
${ }^{35}$ Case of Ireland, 143.

${ }^{36}$ Case of Ireland, 17.

${ }^{37}$ Case of Ireland, 22.
} 
Henry II was really a consensual accommodation between the people of Ireland and their new king.

Consequently Molyneux was satisfied that no laws had been imposed upon 'the People of Ireland' except by their consent. ${ }^{38}$ As he took pains to emphasise, this legislative independence was vital to the security of the lives, liberties and estates of his countrymen. It was fundamental to the liberties of the English, which were based upon 'that Universal Law of Nature ... of being Govern'd only by such Laws to which they give their own Consent by their Representatives in Parliament' ${ }^{39}$ Later on, concluding a survey of English acts affecting Ireland since the Restoration, he asserted that 'the Right of being subject Only to such Laws to which Men give their own Consent, is so inherent to all Mankind, and founded on such Immutable Laws of Nature and Reason, that 'tis not to be Alien'd, or Given up, by any Body of Men whatsoever'. And he made the same point most forcefully and succinctly in his conclusion, where he declared that 'I have no other Notion of Slavery, but being Bound by a Law to which I do not Consent. ${ }^{40}$

The people of Ireland

We have seen that Molyneux traced the Anglo-Irish connection back to the pact allegedly made by Henry II and the Gaelic chieftains who willingly submitted to him. For many Irish historians the fascination of the Case of Ireland lies in the belief that this ancient

\footnotetext{
${ }^{38}$ Case of Ireland, 38.

${ }^{39}$ Case of Ireland, 48, 56.

${ }^{40}$ Case of Ireland, 113, 169.
} 
constitution, appropriated from the dispossessed Catholic elite, constituted a bridge connecting a newly emerging Protestant patriotism with older Catholic notions of Irish nationhood. But the same scholars agree that Irish patriot discourse suffered from a fatal contradiction. The ancient Irish constitution was founded on an original contract made between the English monarchy and the people of Ireland. But the people in question were the native Irish and the 'Old English' (those settlers of medieval origin who had mostly remained faithful to Rome). The overwhelming majority of Irish parliamentarians, on the other hand, were of neither Gaelic nor Anglo-Norman stock but were the descendants of the Protestant families who had acquired their estates as a result of sixteenth and seventeenth-century confiscations. The identification of this Protestant colonial caste as the people of Ireland has generally been viewed as a blatant imposture; if there had been a compact made between the Crown and the Irish nation surely 'it was a nation that Molyneux's own ancestors had subsequently deprived of its property and civil rights' ${ }^{41}$ Nowhere was this subterfuge more shameless than in Molyneux's infamous comment that 'the great Body of the present People of Ireland' consisted of the descendants of English settlers, while 'there remains but a meer handful of the Antient Irish at this day; I may say, not one in a thousand'. ${ }^{42}$

Molyneux's attempt to eliminate the Gaelic Irish from political calculations has become the most-cited passage of his entire treatise..$^{43}$ It is certainly a revealing comment, but not for

\footnotetext{
${ }^{41}$ R. F. Foster, Modern Ireland, 1600-1972 (London, 1988), 161.

${ }^{42}$ Case of Ireland, 20.

${ }^{43}$ It is the subject of interesting comments in Jim Smyth, "Like amphibious animals": Irish Protestants, ancient Britons, 1691-1707', Historical Journal, 36 (1993), 789-90, and Jacqueline Hill, 'Ireland without union: Molyneux and his legacy', in Robertson (ed.), Union for empire, 280-81.
} 
the reasons usually suggested. The point at which the native population conveniently leaves the national stage occurs during Molyneux's examination of the rights that might properly be said to accrue to a just conqueror. As we saw earlier, Molyneux faithfully paraphrased chapter sixteen of the Second treatise, in which Locke explained that whatever rights might be claimed by a victor in a just war, these could never be applied to his own military forces. Even if William of Normandy had conquered England - 'as by the History it appears otherwise' - Locke insisted that his dominion would extend only to 'the Saxons and Britains, that were then Inhabitants of this Country'. The Normans and their descendants could not be subject to the conquering power but rather shared in the exercise of it, retaining their status as freemen. Locke concluded triumphantly that 'if I, or any Body else, shall claim freedom, as derived from them, it will be very hard to prove the contrary'. ${ }^{44}$ This line of reasoning is the only echo in the whole Second treatise of the historical debates on the ancient constitution; it is interesting, nevertheless, because it shows that even Locke could not completely escape the long-running historical debate over the antiquity of the house of commons which played such a pivotal role in Restoration politics.

Molyneux summarised Locke's paragraph, adding that precisely the same logic could be applied to the expedition of Henry II. It was only 'the Antient Race of the Irish', those who opposed the king in arms, who could be deprived of their liberty and property. The Englishmen who accompanied him retained all 'the Freedoms and Immunities of Free-born Subjects'. This was the moment when Molyneux observed that 'the great Body of the present People of Ireland, are the Progeny of the English and Britains that from time to time have come over into this Kingdom'. Having reduced the natives to a statistical irrelevance,

\footnotetext{
${ }^{44}$ Peter Laslett (ed.), John Locke: Two treatises of government, (Cambridge, 1988), 387.
} 
he finished, exactly like Locke, with the argument that 'if I, or any body else, claim the like freedoms with the Natural Born Subjects of England, as being Descended from them, it will be impossible to prove the contrary. ${ }^{45}$

It was J. G. Simms who first complained that Molyneux relegates the Gaelic Irish to the status of 'non-persons' ${ }^{46}$ One problem with this accusation is that most seventeenthcentury people were non-persons in any case. Contemporaries showed little dissatisfaction with the tortuous restrictions and irregularities of parliamentary representation, so contrary to modern democratic assumptions. There is no way of accurately calculating the size of the Irish electorate. It has been estimated that one fifth of adult males in England and Wales had the right to vote (a higher proportion than at any time before the 1832 Reform Act) ${ }^{47}$ In Ireland the number of voters was smaller, with between 3,000 and 3,500 in Dublin in 1713, but tiny figures elsewhere (162 in the Country Londonderry by-election of $1697 ; 400$ in the Carlow by-election of 1725). Only a small proportion of the Protestant population actually participated in the electoral system, and tenants were expected to cast their votes, in any case, as their landed proprietors directed. ${ }^{48}$

The size and composition of the actual electorate was in keeping with the restricted definition of 'the people' current in late seventeenth-century thought, even among advanced whigs. Although Locke has sometimes been portrayed as a radical populist, his

\footnotetext{
${ }^{45}$ Case of Ireland, pp. 19-20.

${ }^{46}$ J. G. Simms, William Molyneux of Dublin (1982), 105.

${ }^{47}$ Geoffrey Holmes, Politics, religion and society in England: 1679-1779 (London, 1986), 14.

${ }^{48}$ D. W. Hayton, 'Voters, patrons and parties: parliamentary elections in Ireland, c. 1692-1727', in Clyve Jones et al. (eds.), Partisan politics, principle and reform in parliament and the constituencies, 1689-1880 (Edinburgh, 2005), 50-51, 53.
} 
aim was to destroy absolute monarchy and replace it with parliamentary government and the rule of law, without destabilising the existing social order. He combined a theory of popular sovereignty, in which the formation of political society requires the consent of all men, with the belief that political rights were subsequently restricted to the propertied classes. ${ }^{49}$ The fact that the majority of men (and, of course, all women) were disenfranchised does not seem to have concerned him. ${ }^{50}$ The most influential proponents of the view that government was based on an 'original contract' explicitly rejected the notion that men of property might be outvoted by their servants and labourers. When James Tyrrell maintained that a right of resistance lay in the 'whole people' of England, he meant the three estates of clergy, nobility and commons as opposed to any single one of them. Repeatedly, he reassured his readers that he was talking about the 'sanior pars' or 'Masters of Families, and Freemen', in contrast to the 'rabble', 'vulgar' or the 'confused Multitude' ${ }^{51}$ The whig theorist William Atwood was alarmed by Locke's account of resistance to tyrannical rulers, which he believed would produce social as well as political dissolution. Political action was the business of landowners, he cautioned, not 'Copyholders, Servants, and the very Faeces Romuli. ${ }^{52}$ In both writers, the reader senses that

\footnotetext{
${ }^{49}$ Ron Becker, 'The ideological commitment of Locke', History of Political Thought, 13 (1992), 631-56; Ellen Meiksins Wood, 'Locke against democracy: consent, representation and suffrage in the Two treatises', History of Political Thought, 13 (1992), 657-89.

${ }^{50}$ A view not significantly revised by the discoveries discussed in Mark Knights, 'John Locke and postrevolutionary politics: electoral reform and the franchise', Past and Present, 213, no. 1 (2011), 41-86. Proposals for parliamentary reform during this period generally generally aimed to strengthen rather than weaken the link between property and political participation: see D. W. Hayton, The house of commons, 1690-1715, I: Introductory survey and appendices (Cambridge, 2002), 254-261.

51 Julia Rudolph, Revolution by degrees: James Tyrrell and whig political thought in the late seventeenth century (Basingstoke, 2002), 133-35, 140-41.

52 William Atwood, The Fundamental constitution of the English government (1690), 100-101. The Latin reference is to Cicero, ad Att. 2.1.
} 
'the people' was not merely a restricted social category but a constitutional construction. The breaking of the contract between James II and the English people, Atwood specified, meant that power devolved to those who had 'Legal Interests in the Government' ${ }^{53}$

Molyneux thus inhabited a mental world in which most people in Ireland did not actually belong to 'the people of Ireland'. Once we adjust our understanding of 'the people' to match the realities of the unreformed electoral system, Molyneux's arithmetic becomes less scandalizing. It was certainly less unusual than we might think. In his influential and muchreprinted treatise, A discovery of the true causes why Ireland was never thoroughly subdued (1612), Sir John Davies claimed that an Irish census poll would reveal that those of English descent now outnumbered 'the ancient Natives. ${ }^{\prime 54}$ More recently, the economic writer Sir Walter Harris had suggested that as many as three quarters of Ireland's Catholics were 'of Brittish Extraction'. ${ }^{55}$ Another pamphlet of 1691 acknowledged that the 'meaner sort of the People' included many of 'Ancient Irish Extraction' but the nobility and gentry were of English stock - although a shared hostility to Protestantism had, over time, ensured their assimilation to the native population. ${ }^{56}$ As late as 1751 it was possible for the Archbishop of Armagh to write that ' $[\mathrm{t}]$ he present Inhabitants of this Kingdom are almost all descended from English families' ${ }^{57}$

\footnotetext{
${ }^{53}$ Atwood, Fundamental constitution, 98.

${ }^{54}$ Sir John Davies, A discovery of the true causes why Ireland was never thoroughly subdued (London, 1612$), 3$.

${ }^{55}$ Sir Walter Harris, Remarks on the affairs and trade of England and Ireland (London, 1691), 28.

${ }^{56}$ England undeceived. In answer to a late pamphlet, (intituled, Some ways for raising of money...) (London, 1691), 9.

${ }^{57}$ George [Stone], A sermon preached in Christ-Church, Dublin, on Wednesday the 23d of October, 1751 (Dublin, 1751), 26.
} 
In order to recapture Molyneux's intellectual world in its full strangeness, however, we need to appreciate that not only was the social extent of 'the people' irrelevant to his purposes, but so too was the question of its ethnic composition. We tend to assume that Molyneux wrote with the intention of ratifying the monopolisation of social and political power by his colonial class, re-established so recently and with so many lives lost. But this is to wrench his words out of their seventeenth-century surroundings. Like Locke, as we have just seen, Molyneux's analysis of conquest was driven by the entirely negative purpose of insulating himself against a specific danger - that the past subjugation of any one section of Ireland's inhabitants might provide a precedent for the exercise of arbitrary rule over all of them. His goal was to demonstrate, in language that English whigs would find compelling, that the Dublin parliament was not the unilateral creation of any single agent, and that consequently its privileges could not be unilaterally revoked. It was England's experience of invasion and colonial settlement rather than Ireland's that generated the hypersensitivity of constitutional writers concerning the relations of conqueror and conquered, and hence determined the basic structure and core themes of Molyneux's work.

It should now be clear that to describe the Case of Ireland as an adaptation of Locke's Two treatises to Irish conditions is also very inadequate. The name of Locke was certainly invoked at a number of points, alongside the 'civilians' Grotius and Pufendorf, the two great pioneers of the Protestant tradition of natural law, and the Anglican theologian Richard Hooker. ${ }^{58}$ Towards the end of the Case of Ireland, when Molyneux resumed his argument that binding Ireland without its consent was an infringement of 'the Common Rights of all Mankind', he also included a short précis of Locke's account of the state of nature, to show

\footnotetext{
${ }^{58}$ Molyneux, Case of Ireland, 151, 153.
} 
that all political obligation was based on the voluntary decision of men to give up their state of natural freedom and equality and to enter into civil society for the common benefit of all. ${ }^{59}$ But Molyneux had no intention of engaging seriously with Locke's conception of the state of nature, with its distinctive mix of post-Calvinist theology and nascent anthropology, nor with the right of resistance and the dissolution of government, the culminating doctrine of the entire work.

As Pocock realised over half a century ago, Molyneux belongs to the second group of Robert Brady's turbulent men, those who sought to demonstrate that England was a constitutional monarchy on the 'Antient Rights and Privileges' and consequently turned to 'Records, and Histories, in Charters, and other Monuments of Antiquity'. ${ }^{60}$ Pocock was the first to discover that the debates over crown and parliament in Stuart England bore little relation to the great systems of patriarchal and natural rights elaborated by Filmer and Locke and taken by political philosophers to be representative of that age. Instead, the theorists of that violent century were consumed by a series of historical and legal disputes over the origins of English parliamentary institutions and the common law, which together formed the allegedly ancient constitution of the realm. The key question for the whig constitutional writers of the Restoration was that of how far the Norman Conquest had disrupted Anglo-Saxon political and legal institutions. According to royalist scholars such as Sir Robert Filmer and later Robert Brady, the invasion of 1066 was an absolute conquest, erasing the existing laws and rights of the English; subsequent grants of rights, such as Magna Carta, and the institution of parliament itself, were later developments, whose validity depended on royal

\footnotetext{
${ }^{59}$ Case of Ireland, 150.

${ }^{60}$ Robert Brady, An introduction to the old English history (London, 1684), [A3 $\left.{ }^{\mathrm{v}}\right]$.
} 
acts of grace. Whigs, conversely, denied that the continuity of Saxon rights and liberties had been interrupted by the conquest of 1066 .

Thus the common lawyer William Petyt, whose influential Antient right of the commons in England asserted appeared in 1680, emphasised that William of Normandy had confirmed the laws of the Edward the Confessor as a condition of his accession, and traced the rights of the English house of commons back through the curia regis of the Normans to the witenagemot of the Anglo-Saxons. But Petyt and his disciples went further still, arguing that this Saxon assembly was itself descended from the concilium of the ancient Britons. His pupil William Atwood refused to accept the idea that the Normans had conquered the Saxons, but also denied that the Saxons had conquered the Britons, preferring to stress that Ina, the first Saxon king, had married into the British line of Cadwallader. As Colin Kidd has emphasised in his important study, British identities before nationalism (1999), whigs claimed that the laws of England had remained substantially unaltered since the days of the ancient Britons, despite the invasions of Romans, Saxons, Danes and Normans. A closer parallel to the Irish case can be found in Scotland, where lowland elites engaged in the extirpation of Gaelic culture nevertheless buttressed their parliament and their church with political and ecclesiastical myths rooted in the Dalriadic past. In the peopling of Britain and Ireland by waves of invading groups what mattered, as Kidd has convincingly shown, was the alteration of political systems, by force or by compact, rather than the clash of ethnic communities. ${ }^{61}$ For Scots and Irish 'patriots', as for their English whig counterparts, the imperative was to demonstrate was that executive authority had always been exercised

\footnotetext{
${ }^{61}$ Colin Kidd, British identities before nationalism: ethnicity and nationhood in the Atlantic world, 1600-1800 (Cambridge, 1999).
} 
within constitutional limitations. The question of who enforced those limitations seldom arose, a point best demonstrated by turning to Molyneux's critics.

The defenders of empire

The responses to the Case of Ireland in England have been casually dismissed by one Irish historian as 'a mixture of derision, scorn, and abuse'.$^{62}$ It is only very recently, with the publication of Marie Leoutre's article on Simon Clement, that they have been taken seriously. ${ }^{63}$ By far the best known was written by Charles Davenant, considered by Istvan Hont to be the key exponent of political economy in the era after $1688 .{ }^{64}$ His Discourse on the plantation trade (1698) remained 'the most important discussion of commerce, colonies and empire' for half a century. ${ }^{65}$ Davenant drew upon Simon Clement, author of the anonymous The interest of England (1698), a response to Annesley's Some thoughts on the bill, which had appeared early in 1698 and focussed mostly on Anglo-Irish trade. ${ }^{66}$ But it was obvious that Molyneux would have to be confronted on his own ground, that of the ancient constitution, and Clement accordingly prepared a much weightier piece, An answer

\footnotetext{
62 Thomas Bartlett, “'A people made rather for copies than originals”: the Anglo-Irish, 1760-1800', International History Review 12.1 (Feb. 1990), p. 15.

63 Marie Léoutre, 'Contesting and upholding the rights of the Irish parliament in 1698: the arguments of William Molyneux and Simon Clement', Parliaments, Estates and Representation, vol. 34, no. 1 (2014), 2-39.

${ }^{64}$ Istvan Hont, Jealousy of trade: international competition and the nation-state in historical perspective (London, 2005), ch. 3.

${ }^{65}$ Miller, Defining the common good, 155-56.

${ }^{66}$ [Simon Clement], The interest of England, as its stands with relation to the trade of Ireland (London, 1698). Annesley's pamphlet was reprinted in Dublin in April, prompting this characteristically belligerent praise from King: 'I believe the English of Ireland will never Rebell agst England, but if they do, they need only reprint this pamphlet to Justify them.' King to Annesley, 30 April 1698, TCD MS 750/1/220.
} 
to Mr. Molyneux his case of Ireland's being bound by acts of parliament in England, stated ${ }^{67}$ Although he had previously confined his writings to the analysis of international trade, and especially questions of currency, Clement now plunged into the arcana of the statute books, the parliamentary rolls and the medieval chronicles.

Clement seems to have been connected with John Cary, the Bristol merchant who, as we have already seen, led the campaign against Irish woollens since $1695 .{ }^{68}$ In August 1698 Cary would contest the Bristol election on anti-Irish platform, unsuccessfully, it turned out. His demand then was that Ireland should be 'reduced to the state of our other Colonies', and more specifically to a dependency of his own city, Bristol, whose rightful position was as 'the Metropolis of Trade to Ireland' ${ }^{69}$ His Vindication of the parliament of England, in answer to a book, written by William Molyneux of Dublin was dated 16 June. It also tracked Molyneux through the various precedents he had produced, citing legal and constitutional authorities such as Matthew Paris, Edward Coke, Prynne, and the Irish Modus, and devoting a large amount of space to the creation of a separate lordship of Ireland for John, son of Henry II, in 1177, and to the Irish 'Magna Carta' granted by Henry III in 1216. Altogether these legal matters took up 110 out of Cary's 127 pages. ${ }^{70}$ Another substantial reply appeared sometime after June, written by the barrister William Atwood, described by

\footnotetext{
${ }^{67}$ As the full title made clear: [Simon Clement], An answer to Mr. Molyneux his Case of Ireland's being bound by acts of parliament in England, stated: and his dangerous notion of Ireland's being under no subordination to the parliamentary authority of England refuted (London, 1698).

68 Perry Gauci, The politics of trade: the overseas merchant in state and society, 1660-1720 (Oxford, 2001), 189, note 74. Clements' relationship with Cary, with Locke and other members of the 'College' and with the junto whig Lord Somers would all repay further investigation. On Somers see D. W. Hayton, Ruling Ireland, 1685-1742: politics, politicians and parties (Woodbridge, 2004), 68-70.

${ }^{69}$ See [John Cary], To the freeholders and burgesses of the city of Bristol (1698), 4.

70 John Cary, A vindication of the parliament of England, in answer to a book, written by William Molyneux of Dublin (London, 1698).
} 
Laslett as 'the worst of the whig constitutional writers'. ${ }^{71}$ Atwood had been a pupil of Petyt and a pamphlet warrior of the Exclusion Crisis, having previously defended parliamentary rights in Jani anglorum facies nova (1680) and Jus anglorum ab antiquo (1681). Following the revolution he returned with The fundamental constitution of the English government (1690), an extensive compilation of historical precedents designed to prove that English kingship had always functioned by consent, that monarchy had always been elective, and that the English had a long and venerable tradition of deposing their kings. His riposte to Molyneux was entitled The history, and the reasons, of the dependency of Ireland upon the imperial crown of the kingdom of England (1698). ${ }^{72}$

It is unfortunate that the rejoinders produced by Atwood and his colleagues have been overlooked by British as well as Irish historians, because they occupy an interesting position in the history of British imperial thought. The problem of Irish commercial competition took up thirty pages of Davenant's ambitious Essay upon the probable methods of making the people gainers in the balance of trade (1699). This impressive exercise in political arithmetic aimed to show 'how the Wealth and Strength of England is to be secur'd and improv'd' ${ }^{73}$ He argued that the development of the Irish woollen trade represented a threat to England's markets and should therefore be crushed before it acquired real momentum. ${ }^{74}$ This 'severe Wisdom' was necessitated by the centrality of commercial empire to England's

\footnotetext{
${ }^{71}$ Laslett (ed.), Two treatises, 77, footnote.

72 On Atwood, see Melinda S. Zook, Radical whigs and conspiratorial politics in late Stuart England (University Park, PA, 1999), 66-75.

${ }^{73}$ Charles Davenant, An essay upon the probable methods of making the people gainers in the balance of trade (London, 1699), 6.

${ }^{74}$ Hont, Jealousy of trade, 58-62, 222-33.
} 
war-making capacity in the era of Louis XIV. ${ }^{75}$ The political status of the kingdom of Ireland was analysed with the same brutal clarity:

When a part of the People divides from the rest to seek more Territory, if they are at their own Cost, and strong enough to eradicate or keep under the Natives, they become a New Empire, and may be justly term'd a distinct Nation: But if not at their own Expense, and if they are a weak and always stand in need of being protected by their Mother-Country, they are in all appearance to be accounted but as a Colony. ${ }^{76}$

Simon Clement agreed that England must pursue 'all justifyable Methods for the preserving her Commerce', including the regulation of colonial trade, because this was the basis for her naval and military power, and hence the protection of the entire system. Consequently England must have the right to bind its all its dominions by legislation since it was 'the Head of this Empire, from whence all its Members do derive their Being' ${ }^{77}$

For the most part, however, the focus of Molyneux's critics was not 'jealousy of trade' but the ancient constitution. His assailants anticipated many of the arguments employed against the American colonists in the 1760 s and 1770s. Jack Greene has interpreted the American Revolution as the collision of two rival conceptions of empire, the one a unitary system with legislative authority concentrated at the centre in the shape of the British parliament, the other a federal conception of empire in which sovereignty was dispersed

\footnotetext{
${ }^{75}$ Davenant, Probable methods, 125.

${ }^{76}$ Davenant, Probable methods, 114.

77 [Clement], Answer to Mr Molyneux, 72-73.
} 
among different colonial representative assemblies. ${ }^{78}$ In their opposition to metropolitan interference in their domestic affairs, the Americans maintained that 'no man is bound by any law to which he hath not given his consent either in person or by a representative', and that 'the liberties of an Englishman' applied throughout the British dominions. ${ }^{79}$ It is hardly surprising, then, that we should find Benjamin Franklin sending a copy of Molyneux to a friend in 1770, noting the similarities between the American and Irish examples, or that excerpts of the Case of Ireland appeared in the Boston Gazette in the following year, suitably adapted to American circumstances. ${ }^{80}$

All the English constitutionalists who wrote against Molyneux believed that Ireland was a colony of England. The Dublin parliament, they supposed, should therefore be classified along with the 'Proprietoryships' granted to the settlers in North America. At the same time, those who sought to cut the Dublin patriots down to size drew parallels between Ireland and the palatine counties of Chester and Durham, which had regalia powers but not parliamentary representation: this move would also be employed against the Americans during the Stamp Act crisis of the 1760s. ${ }^{81}$ This haziness about the status of the kingdoms and colonies attached to the British monarchy should not surprise us. Economic writers, most prominently Davenant, had analysed colonial possessions as sources of raw materials

\footnotetext{
78 Jack Greene, Peripheries and center: constitutional development in the extended polities of the British empire and the United States, 1606-1788 (London, 1986), chs. 1-7.

79 Jack P. Greene, The constitutional origins of the American revolution (Cambridge, 2011), xviii, 7, 79-82, 118, 131. The quotations are from John Joachim Zubly, Great Britain's right to tax her colonies (London, 1774), 4.

80 Neil Longley York, Neither kingdom nor nation: the Irish quest for constitutional rights, 1698-1800 (Washington, D.C., 1994), 87, 91-2.

${ }^{81}$ See for example [Clement], Answer to Mr. Molyneux, 44; W[illiam] Atwood, The history, and the reasons, of the dependency of Ireland upon the imperial crown of the kingdom of England (London, 1698), 60; John Phillip Reid, Constitutional history of the American revolution: abridged edition (London, 1995), 43-44.
} 
and markets for finished products, but the discussion of Britain's maritime empire was limited to writings on international trade. The legal and constitutional status of the colonies had never been adequately defined on a theoretical level. Even within England itself, the character of the parliamentary monarchy emerging in the 1690 s was dimly understood, and it was not until the middle of the eighteenth century that the concept of a sovereign, lawmaking parliament won widespread acceptance.

Another way in which English responses to Molyneux anticipated the imperial crisis of the 1760s and 1770s was by advancing a distinction between internal and external spheres of authority. It was entirely reasonable, they granted, that the gentlemen of Ireland should have a local assembly to make 'private Laws' for their domestic affairs. ${ }^{82}$ Interestingly, Clement and Atwood both specified that taxation belonged to this devolved sphere; the 'supream' authority did not necessarily enjoy the right to tax without consent. ${ }^{83}$ Beyond these domestic representative bodies, however, there had to be an overriding law for the empire - to maintain fleets and armies, and in order to do this, to protect commerce. While Davenant thought it was indisputable that Ireland possessed its own 'Inferior Rule and Jurisdictions' he could not accept that the Protestants of Ireland possessed 'Super-eminent Dominion and supream and uncontrollable Regiment over themselves' - this would be incompatible with the national security of England. ${ }^{84}$ Clement similarly insisted that the Supream Legislature of the whole Body' must be fixed permanently in what he called its

\footnotetext{
${ }^{82}$ Cary, Vindication, 96; [Clement], Answer to Mr. Molyneux, 65.

${ }^{83}$ Clement, Answer to Mr. Molyneux, 71; Atwood, Dependency of Ireland, 207-08.

${ }^{84}$ Davenant, Probable methods, 117.
} 
'Head', as defined by the original constitution, and could never be alienated or shared with subordinate 'Members': 'Can any thing grant away it self?'85

None of Molyneux's adversaries denied his central claim, that it was a fundamental right of Englishmen to be governed only by laws enacted with their own consent. Admittedly, Davenant was somewhat evasive on this point, at least where the native Irish were concerned. Whatever concessions had been made to them by Henry II at Cashel, he believed, had been cancelled out by the 52 insurrections fomented by the intractable natives. They had accordingly forfeited what Davenant vaguely termed 'certain Priviledges not Fundamental'. In any case, the civil status of the indigenous population was hardly relevant, since he agreed with Molyneux that the Gaels were now only a 'Thousandth Part' of the island's inhabitants. The real question was the position of the settler population which was 'now properly the Body-Politick' ${ }^{86}$ The dispute about their position was shortcircuited by Davenant's repeated reminders that they were dependent on England for protection and consequently owed obedience. It was fair enough that Ireland should hold parliaments to consider its own affairs, but the proper place for deliberation upon matters that affected 'the whole' was the parliament of England, 'by whose Arms and Treasures Ireland ever was, and must always be defended' ${ }^{87}$

The other three respondents - all of them whigs - felt it necessary to give an answer that preserved more carefully English constitutional proprieties. Atwood helpfully pointed out that the privilege of electing members of parliament was denied to many inhabitants of

\footnotetext{
85 [Clement], Answer to Mr. Molyneux, 65.

${ }^{86}$ Davenant, Probable methods, 109, 111-12. Davenant's own term was the 'English-Irish': 117.

${ }^{87}$ Davenant, Probable methods, 116.
} 
England itself, and so Ireland had nothing to complain about. The existence of a large pool of disenfranchised did not present serious difficulties to whig ideology, because these men had been 'concluded by the consent of their Forefathers' and by their own willingness to remain in a kingdom 'govern'd by such Laws, to which they owe Obedience and Submission, at least as long as they will receive the benefit of them, and the protection which they assure' ${ }^{88}$ This view corresponds to that of Locke, who seemed to think there were two ways in which the consent of the individual functioned to legitimise political arrangements. The first was when men united to preserve their 'lives, liberties and estates' by agreeing to the formation of a legislative authority. By doing so they incorporated themselves into a commonwealth or state, coming together 'to make one People'. Locke is explicit that once incorporated into the body politic the majority acts for the whole, by consenting to specific legislation. But rather than develop this distinction further, Atwood stuck to the general, practical point that the security of Irish Protestants rested on the protection of England: 'and if their Consciences are squeamish, let them renounce their Right to the Lands of the Natives' ${ }^{89}$

This was not the only way to get around the problem of colonial obligation to English legislative authority. Defenders of Westminster parliamentary supremacy assumed that twelfth-century settlers in Ireland must have first have secured explicit permission to emigrate, on condition that they continue to serve the mother country. They and their descendants consequently remained subject to the authority which had allowed them to quit England in the first place. No empirical evidence was produced to support this view,

\footnotetext{
${ }^{88}$ Atwood, Dependency of Ireland, 196.

${ }^{89}$ Atwood, Dependency of Ireland, 198.
} 
but Clement and Cary advanced it nevertheless. ${ }^{90}$ Both writers also denied that planters in Ireland had ever been deprived of the right to elect their own representatives to the 'Supream Legislature' - on the rather improbable grounds that they were free to revisit England if they resolved to exercise the franchise. The position of the colonists was analogous, they assumed, to a trader whose business interests kept him abroad, or an Englishman who undertook a long sea voyage. ${ }^{91}$ An aspiring planter could hardly expect that 'new Itinerant Courts of Parliament shall be erected to follow him, where-ever he thinks fit to remove'. If such a concession were made to the gentlemen of Ireland it would be applicable too to the American plantations, Cary ventured, 'and what a Jumble of Laws should we then have? ${ }^{92}$

Turning to Molyneux's appeal to natural rights, the English whigs protested that such rights belonged to men in their pre-social state but certainly not when living under the political institutions actually existing in civilized societies. The liberty of all mankind to which Molyneux appealed was irrelevant to the Irish Protestants, Clement protested, since it had been surrendered 'when they were in the Loyns of their Ancestors, who consented to the Terms of the Constitution, when they first entred [sic] into Societies'. Perhaps this was a

\footnotetext{
${ }^{90}$ Interestingly, Locke made a similar argument in the Two treatises, distinguishing between tacit consenters, who were free to establish new civil societies 'in vacuis locis', and those who had given express consent to a commonwealth and were 'perpetually and indispensibly obliged to be, and remain unalterably a subject to it'. Discussing this passage, John Dunn could think of no reason why Locke would deny a right of emigration to members of a political society. But the present discussion raises the possibility that Locke's intention was not to prevent emigration but rather to ensure that English settlers would remain under a political obligation to their mother country even when they had established new political structures in 'vacant' lands. See John Dunn, 'Consent in the Political Theory of John Locke' (1967), repr. in his Political obligation in its historical context: essays in political theory (Cambridge, 1980), 42.

${ }^{91}$ [Clement], Interest of England, 22; [Clement], Answer to Mr. Molyneux, 66-67, 95; Atwood, Dependency of Ireland, 212.

${ }^{92}$ Cary, Vindication, 96.
} 
legitimate reading of the Second treatise, as was Clement's later argument that a man who was not born in the state of nature was 'effectually bound by the Consent of his Ancestors, to submit to the Constitution of his Countrey, and that with us determines that the Majority shall bind' ${ }^{93}$ Suspicious of Locke's abstract concepts, mainstream whigs sought instead to establish the continuous existence of a reciprocal relationship between king and subjects, embodied in medieval charters and acts of parliament. For Atwood, the liberty of all men signified 'a total exemption from all Laws and Government, except such as Adam had a right to in the state of Nature' ${ }^{94}$ The concept was only applicable following the dissolution of political authority, but that would also mean the dissolution of the ancient constitution, something Atwood could never countenance. Clement, meanwhile, took the line that Molyneux had 'wholly misapply'd' the natural rights of men:

he abuses Mr. Lock, or whoever was the Author of that Excellent Treatise of Government, in referring to that Book on this occasion; for that Worthy Gentleman doth therein argue the Case of People whose just Rights are violated, their Laws subverted, and the Liberty and Property inherent to them by the Fundamental Laws of Nature, (which he very accurately describes) is invaded and usurp'd upon, and that when this is as Evident and apparent as the Sun that shines in a clear day, they may then take the best occasion they can find to right themselves. ${ }^{95}$

\footnotetext{
${ }_{93}^{9}$ [Clement], Answer to Mr. Molyneux, 76, 156.

${ }^{94}$ Atwood, Dependency of Ireland, 4.

${ }^{95}$ [Clement], Answer to Mr. Molyneux, 30-1.
} 
Although this clash seems to be the first recorded dispute about the meaning of Locke's Two treatises it has not been properly examined by either Irish or British historians. ${ }^{96}$

Molyneux and his critics thus shared a common body of assumptions about the ancient constitution and its role in legitimizing parliamentary institutions; where they differed was on the applicability of this framework of ideas to Ireland. Just how alarming Molyneux's arguments appeared to English constitutionalists is best demonstrated by Atwood's assumption that, since Molyneux was an opponent of the English parliament, he must therefore be an enemy of English liberty. To Atwood the Dublin patriots were ideological allies of the Tory apologists for monarchical absolutism, to be bracketed together with 'Dr Brady and other Advocates for Despotic Power' ${ }^{97}$ This was the same Robert Brady, Master of Gonville and Caius College in Cambridge from 1660 to 1700, who provided the startingpoint for Pocock's doctoral research seventy years ago and the subject of his first article. ${ }^{98}$ Brady had been the first scholar to demonstrate that Norman England was a kingdom governed by feudal tenure; that the terms 'populus' and 'libere tenentes' had to be read in the context of the feudal law, and did not mean the same thing as 'people' or 'freeholders' in the seventeenth century; and that the house of commons could be dated no further back than the $49^{\text {th }}$ of Henry III. The perverse effect of Atwood's assault was to transform Molyneux into an anti-parliamentarian.

\footnotetext{
${ }^{96}$ Cf Mark Goldie (ed.), The reception of Locke's politics, 6 vols. (London, 1999), vol. I, pp. xxx-xxxiv.

${ }^{97}$ Atwood, Dependency of Ireland, 'Dedication', [ii].

98 J. G. A. Pocock, 'Robert Brady, 1627-1700. A Cambridge historian of the Restoration', Cambridge Historical Journal, 10 (1951), 186-204.
} 
Perhaps this was simply an opportunistic move, but more intriguing is the possibility that Atwood really meant what he said. In England, the myth of the ancient constitution had supplied critics of the royal prerogative with means of arguing that the king should be bound by the laws of the realm no less than his subjects. Like all good whig parliamentarians, Atwood and his allies obstinately refused to admit that the English monarch had ever acted as a sovereign agent outside the constitutional structure of the ancient constitution. Consequently, the sovereign authority to which Molyneux's Irish chieftains pledged allegiance in 1172 could not have been the king alone, but could only have been, as later generations would put it, the king-in-parliament. When the Irish received the blessing of English laws, they were laws that could not have been made without the consent of 'the States of the Kingdom of England'. ${ }^{99}$ This point was stressed particularly by Clement in his Answer to Mr. Molyneux. When Ireland was pacified by Henry II and his army, Clement assumed, the island became annexed to the imperial crown of England, in other words, to its parliamentary constitution, 'but not to the Person of King Henry, in any separate propriety from the Kingdom' ${ }^{100}$ To imagine that the royal person might have gone around acquiring new kingdoms in his own right might pass in other countries but was 'perfect Nonsence in England'. The static rather than developmental view of history to which whigs subscribed required that England must always have been a limited monarchy, even in the most remote era. Had William of Normandy not acknowledged as much when he was received as king by the people of England following a 'convention' at Berkhamsted where it was agreed that he would uphold the laws of England by a 'mutual

\footnotetext{
${ }^{99}$ Atwood, Dependency of Ireland, 213.

100 [Clement], Answer to Mr. Molyneux, [A5 $]$.
} 
Contract'? ${ }^{101}$ Only then was he crowned according to the customs of the realm, swearing to uphold the laws of Edward the Confessor.

\section{Conclusion}

This article has argued that Irish historians still have much to learn from Pocock's Ancient constitution and the feudal law, both about the intellectual problem that confronted Molyneux and the solution he adopted. Molyneux shared with the English opponents of Robert Brady an overriding anxiety: just like them, he set out to demonstrate that executive power had never operated outside constitutional structures - that the king, that is, had never been in the position of a conqueror who might impose laws on his people. ${ }^{102}$ His appeal to history and legal precedent contrasts with Locke's view that the political relations operating within any actually-existing commonwealth must always be measured against the fundamental rights possessed by human beings in the state of nature - that is the rights which logically flowed from the Christian story of creation. Conversely, it has been suggested here that the Anglo-Irish controversy of 1698 has much to teach historians of the early British empire about how the whig writers of the late seventeenth-century stretched their constitutional theories to deal with the problem of colonial obligation.

That Irish historians for so long paid little attention either to Pocock's monograph or to Laslett's edition is a testament to the inward-looking character of twentieth-century Irish

\footnotetext{
${ }^{101}$ Answer to Mr. Molyneux, [B1']; Atwood, Dependency of Ireland, 45-46.

${ }^{102}$ Here it is worth reiterating that Patrick Kelly is an obvious exception to these strictures. His essay 'Conquest versus consent ... in William Molyneux's Case of Ireland' depicts Molyneux as a writer in the ancient constitution tradition and refers to the Brady controversy $(341,345)$ although his focus on the ambiguities in Molyneux's treatment of conquest takes him in a different direction from the one pursued here.
} 
historiography, lamented by more recent scholars. ${ }^{103}$ It is striking too that there has been relatively little engagement among Irish scholars with the theoretical reflections of the Cambridge school. What made it possible to speak of a cluster of rather disparate intellectual historians as part of a coherent movement was their shared commitment to what is sometimes called linguistic contextualism as a technique for avoiding the anachronism, inaccuracy and absurdity that once afflicted the history of ideas. ${ }^{104}$ Among others, John Dunn, Mark Goldie, James Tully, Annabel Brett, and David Armitage have been associated with the Cambridge approach, but it is above all Quentin Skinner who has investigated the historical meaning of texts and the problems of recovering authorial intention in a series of sophisticated and elegant essays. Skinner's engagement with analytical philosophy, and in particular his adaptation of J. L. Austin's speech-act theory, has spawned a large and lively literature. ${ }^{105}$ Since most historians these days are contextualists by training if not by instinct, they might well wonder why Skinner's famous article 'Meaning and understanding in the history of ideas' (1969) was so controversial, and why it is so widely cited and discussed 50 years after its publication.

Situated uneasily between the disciplines of History and Philosophy, those who taught the history of political ideas during the 1950s and 1960s lived a curious, amphibious existence. In the Philosophy departments students were initiated into the canon of Western political

\footnotetext{
${ }^{103}$ Alvin Jackson, 'Irish history in the twentieth and twenty-first centuries', in idem (ed.), The Oxford handbook of modern Irish history (Oxford, 2014), 15-16.

${ }^{104}$ Mark Bevir, 'The contextual approach', in G. Klosko (ed.), The Oxford handbook of the history of political philosophy (Oxford, 2011), 11-23.

${ }^{105}$ Skinner has now been the subject of many books himself, including James Tully (ed.), Meaning and context: Quentin Skinner and his critics (Princeton, NJ, 1988); Kari Palonen, Quentin Skinner: history, politics, rhetoric (Cambridge, 2003); and Annabel Brett and James Tully with Holly Hamilton-Bleakley (eds.), Rethinking the foundations of modern political thought (Cambridge, 2006).
} 
thought in a manner that was strikingly unhistorical. They were taught to extract from the canonical texts principles of universal value, or to resolve the apparent contradictions in the works of Plato, Machiavelli, or Locke as if performing an exercise in biblical exegesis. Skinner was infuriated by the tendency to anachronism inevitable in this approach, as the classic texts were read as solutions to the allegedly 'perennial' problems of political philosophy rather than addressing the particular issues of their times. In the History faculties, meanwhile, the attitude towards intellectual historians was dismissive. Namierites viewed political rhetoric as a distraction from the networks and interests that really explained the motivations of political actors. Marxists assumed that Hobbes and Locke must be read as ideological advocates of the emerging market society of the seventeenth century. The leading Tudor historian Geoffrey Elton, who belonged to neither of these schools but was a intractably old-fashioned archival scholar, spoke for the mainstream when he suggested that the proper place for intellectual historians was in the 'scullery' rather than the 'drawing room'. ${ }^{106}$

Skinner thus found himself fighting on several fronts simultaneously. The act of liberating the subject material from political philosophy was never simply a matter of correcting anachronisms, but had to be defended in terms to which the philosophers themselves would submit. His key inspiration was the Oxford Idealist R. G. Collingwood, who had convinced Skinner that philosophical texts should be read as attempts to solve the specific problems of their times, and that we must therefore reconstruct as precisely as possible the questions that most troubled their authors. Skinner next turned to Austin's 'speech-act'

\footnotetext{
${ }^{106}$ Quentin Skinner, Visions of politics, volume I: regarding method (Cambridge, 2002), 14, quoting from Elton's Return to essentials (Cambrige, 1991).
} 
theory which treated verbal utterances as linguistic performances: the vital question was not what words mean but how they are used. Since it is impossible to understand why a writer employed particular words and phrases without establishing their conventional use in pre-existing and contemporary debates, the task of the historian was first and foremost to familiarise him- or herself with the widest range of related texts, in order to achieve the fullest possible understanding of the range of intellectual materials available.

No doubt many historians regard these recherché disputes as irrelevant to the real business of research. But Skinner's conviction that we should concern ourselves not simply with what texts said, but with what they were doing, has offered an extremely persuasive model of interpretation, producing a more dynamic, dialogic understanding of the text as a political intervention. For Skinner the fundamental questions always concern the range of actions which writers might be said to perform - affirming, subverting, satirising or reiterating the established ideas and norms of their time. Even critics allow that Skinner's adaptation of speech-act theory remains 'an innovative and valuable guide to historical practice, and one of the most reliable methods of gleaning authorial intentions' ${ }^{107}$

J. G. A. Pocock has also written extensively about method, but he is the first to admit that his engagement with philosophy has been 'casual'. ${ }^{108}$ Skinner's research projects, right from the beginning, were conceived as exemplifications of a philosophical position. By comparison Pocock's methodological writings have consisted of homespun reflections on his practice. His chief contribution has been to popularise the study of previously neglected 'languages' or 'discourses' of politics - largely discrete structures of thought whose key

\footnotetext{
${ }^{107}$ Robert Lamb, ‘Quentin Skinner's “post-modern” history of ideas, History, 89 (2004), 424-433.

108 Pocock, 'Quentin Skinner', 127.
} 
concepts are not readily translated into the dominant tradition of liberalism. When Pocock drew on philosophers such as Michael Oakeshott, it was to supply illustrations or metaphors for his existing practice rather than to construct a precise theoretical justification of it.

This observation applies also to Pocock's appropriation of the concept of 'paradigm' from Thomas Kuhn's celebrated Structure of scientific revolutions (1962). Kuhn argued powerfully that scientific communities normally based their investigations on a successful linguistic or theoretical model, which not only structured the answers to questions, but determined what kinds of question it was possible to ask. These paradigms were transmitted from one generation to the next by professional training and socialisation. By analogy, the priority for the intellectual historian was "to identify the "language" or "vocabulary" with and within which a particular author operated, and to show how it functioned paradigmatically to prescribe what he might say and how he might say it'. ${ }^{109}$ One of Kuhn's critics famously complained that his book had employed the word 'paradigm' in twenty-one different senses, and it is equally true that Pocock's 'languages' operate at a number of levels of generality. ${ }^{110}$ The attraction for Pocock, however, was Kuhn's emphasis on the unconscious constraints imposed by paradigms: we are unable to see outside them. ${ }^{111}$ Like Collingwood, Kuhn became an emblematic figure for historians who believed that the propositions and arguments of the canonical political philosophers only made sense in relation to patterns of thought that have long since vanished. While talk of 'paradigms' and 'languages' alienated

\footnotetext{
$109 \mathrm{~J}$. G. A. Pocock, 'Languages and their implications', in Politics, language and time: essays on political thought and History ( $2^{\text {nd }}$ edn., London, 1989), 25.

${ }^{110}$ Margaret Masterman, 'The nature of a paradigm', in Imre Lakatos and Alan Musgrave (eds.), Criticism and the growth of knowledge, (Cambridge, 1970), 61. For criticisms of Pocock on this score see Alan Cromartie, 'Harringtonian virtue: Harrington, Machiavelli, and the method of the moment', Historical Journal 41 (1998), 987-1009.

${ }^{111}$ Pocock, 'Languages and their implications', esp. 13-14.
} 
some readers, it inspired a new generation of research students, for whom these terms expressed something of the imaginative effort involved in restoring texts to their original intellectual environments.

The irresistibility of Swift and Burke for historians of Ascendancy Ireland meant that R. B. McDowell, J. C. Beckett and others sometimes found themselves writing the history of political thought. Like most historians, however, the men who wrote the eighteenth-century volume of the New history of Ireland tended to avoid theoretical statements altogether. Specialisation in intellectual history was a luxury this small group could seldom afford, but it must have seemed superfluous too. ${ }^{112}$ What made the Cambridge project exciting and subversive was above all the determination to collapse the canonical works into the broader stream of past political discourse. But in Ireland there were no great texts to be prised out of the philosophers' hands. The generation of Beckett and McDowell had a powerfully internalised sense that neither Ireland's historians nor their subjects were of much interest to the rest of the world, which mostly meant Britain. Beckett's final verdict on Molyneux was that he failed to give his ideas 'a more than local significance'. ${ }^{113}$ The posthumous appearance of J. G. Simms's William Molyneux of Dublin (1982) helped to stimulate wider interest in the Case of Ireland; but, revealingly, Pocock does not appear in his bibliography. This valuable book was prepared for publication by Patrick Kelly, who arrived at Trinity, by way of Cambridge, in the early 1970s, and who would go on to produce the first systematic studies of the Case of Ireland. Kelly had written a PhD on Locke's economic thought under the

\footnotetext{
112 D. G. Boyce and R. R. Eccleshall (eds.), Political ideas in Ireland since the seventeenth century (London, 1993), was the first book to set out a 'Cambridge' programme for Irish history (see the editors' introduction, 1-6).

113 J. C. Beckett, 'Literature in English, 1691-1800', in T. W. Moody, and W. E. Vaughan (eds.), A new history of Ireland, vol. IV: Eighteenth-century Ireland 1690-1800 (Oxford, 1986), 457.
} 
supervision of Peter Laslett himself, and he regarded Laslett's 'magnificent' edition of the Two treatises as his model. ${ }^{114}$ He was the first Irish historian to write about political ideas in something like the 'Cambridge style'. ${ }^{115}$

Inevitably, the revolutionary excitement created by the early manifestos of Pocock and Skinner has long since evaporated. The ordinary language philosophy that underpinned the revisionism of the 1960s now appears parochial to a generation schooled on the 'meaning holism' of Quine or, among other varieties of continental philosophy, Foucault's 'regimes of truth'. Skinner's own philosophical commitments have continued to evolve. His more recent work is characterised by an explicit anti-foundationalism, by tentative invocations of Nietzsche and the technique of 'genealogy' advocated by Foucault. ${ }^{116}$ Just how far these newer allegiances necessitate a silent withdrawal from some of Skinner's original methodological positions remains controversial.

In recent years the philosopher Mark Bevir has become Skinner's most determined and influential critic. In formulating his assault on linguistic contextualism, however, Bevir is forced to read both Skinner and Pocock at their most dogmatic. He takes Skinner's position to be that there is only one historical meaning of a text and only speech-act theory can reveal it. ${ }^{117}$ In spite of the combative tone of Skinner's methodological crusade in the

\footnotetext{
${ }^{114}$ P. H. Kelly (ed.), The Clarendon edition of the works of John Locke: Locke on money (2 vols., Oxford, 1991), i. p. xi.

${ }^{115}$ See particularly the two essays cited in footnote 4 , above.

${ }^{116}$ Melissa Lane, 'Doing our own thinking for ourselves: on Quentin Skinner's genealogical turn', Journal of the History of Ideas, 73 (2012), 71-82.

${ }^{117}$ For Bevir's criticisms see 'The errors of linguistic contextualism', History and Theory, 31 (1992), 276-98; 'Contextualism: from modernist method to post-analytic historicism?', Journal of the Philosophy of History, 3 (2009), 211-24; see also Robert Lamb, 'Recent developments in the thought of Quentin Skinner and the ambitions of contextualism', Journal of the Philosophy of History, 3 (2009), 246-65; and, for a qualified defence
} 
1960s, it seems unlikely that he ever seriously held this view. Most of Skinner's allies, including Pocock and John Dunn, have avoided explicit commitment to his distinctive theory of authorial intention. Pocock once wrote disarmingly that his research method was to spend many weeks transcribing passages from a primary text until he had got 'the structure and movement of the book's argument into my bones' ${ }^{118}$ of the many intellectual historians with Cambridge connections, it seems probable that most locate themselves at the softer end of contextualism, where the scrupulous textual criticism, analytical bibliography and archival research pioneered by Laslett weighs more heavily than philosophical commitments to Collingwood or Austin.

This article has applied the contextual method to one particularly influential Irish text, in the hope that we can better understand its 'distinctive shape and character' - why it was structured as it was, why some lines of argument were pursued and others were not. ${ }^{119}$ The attraction of this Skinnerian approach is not just the intensively intertextual nature of the work involved. The Cambridge method also helps to de-familiarise the vocabulary and concepts employed by past writers whom we have too readily assimilated to our own contemporary preoccupations; this must be one reason why its practitioners tend to be early modernists. There would be little point in attempting such an exercise were the existing commentaries on Molyneux not dissatisfying. For a final illustration of the more dialogic approach recommended here, we can turn to Sean Connolly's recent survey,

\footnotetext{
of Skinner, see Timothy Stanton, 'Logic, language and legitimation in the history of ideas: a brief view and survey of Bevir and Skinner', Intellectual History Review, 21 (2011), 71-84.

118 Pocock, 'Working on ideas in time', in Political thought and history, 29.

${ }^{119}$ Quentin Skinner, 'The rise of, challenge to and prospects for a Collingwoodian approach to the history of political thought', in Dario Castiglione and lain Hampsher-Monk (eds.), The history of political thought in national context (Cambridge 2001), 188.
} 
Divided kingdom: Ireland 1630-1800 (2008). It is selected here not because it has egregious shortcomings, but, on the contrary, because Connolly is a notably insightful and experienced historian, who has himself written at length about Irish political thought.

Connolly devotes four pages of his book to the Case of Ireland. He begins by noting that its 'most striking feature' is Molyneux's decision to base claims about the political autonomy of the New English on 'rights granted five centuries earlier to the Gaelic lords whose descendants they had only recently finished dispossessing' ${ }^{120}$ By consigning the indigenous rulers to historical oblivion, Connolly observes that Molyneux was freed from dwelling on the violent upheavals of the sixteenth and seventeenth centuries, the continuing rejection of the Ascendancy order by the majority of Irish people and the reality of Protestant dependence on England. Perhaps this is the moment to acknowledge that one of Molyneux's contemporary critics also noted this troubling feature, or something very like it. In the preface to his Answer, Simon Clement attempted to hoist Molyneux on his own petard:

If Ireland was granted to the Native Irish and Old English, as an Absolute, Independent Kingdom, and was never since re-conquered by England; the Right of administering the publick Affairs of that Government (under the King) ought to remain in them, since 'twas never given up to you by their Consents; and then they have no reason to consider you otherwise, than as ... Usurpers and Oppressors... ${ }^{121}$

\footnotetext{
${ }^{120}$ S. J. Connolly, Divided kingdom: Ireland 1630-1800 (Oxford, 2008), 209-13; quotation on 210. ${ }^{121}$ [Clement], Answer to Mr. Molyneux, [A4v].
} 
Clement goes on to observe, in a memorable phrase, that Molyneux's conflation of the modern English settlers with their Catholic predecessors leaves his Protestant compatriots 'quite unhing'd'. ${ }^{122}$ What is interesting, however, is that Clement then proceeds to address the six arguments made by Molyneux, so that the bulk of his book (171 pages) is taken up with a detailed discussion of all the medieval legal precedents produced by him. Meanwhile, Atwood (216 pages) and Cary (127 pages) said little or nothing at all about the problem of genealogy. Clearly, Molyneux's appropriation of a Catholic constitutional heritage was not as transparent to his contemporaries as it is to modern readers. The major flaw they spotted in Molyneux's notion of an original Irish contract was not that the people of twelfth-century Ireland belonged to a different ethnic group from the Ascendancy class, but rather that Henry II was a parliamentary monarch and that whatever concessions he made to Ireland must have been subject to the consent of the people of England.

Connolly's extended examination of the Case of Ireland next turns to the disappearing Gaels. Once again, it is salutary to discover that Molyneux's contemporary readers, if they noticed this passage at all, seem to have found it uncontroversial. In Connolly's view, each new argument presented by Molyneux about Henry II's invasion undermines the previous one. First he insists that Ireland was never conquered; then he protests that if Ireland was conquered it was only the native Irish who were defeated, a race of people now virtually extinct. Connolly's perceptive treatment concludes that Molyneux was engaged in 'a series of rhetorical retreats', but this verdict doesn't adequately capture Molyneux's technique. ${ }^{123}$ In an earlier essay Connolly described the Case as a 'highly formal chain of reasoning' in

\footnotetext{
${ }^{122}$ [Clement], Answer to Mr. Molyneux, 4, [A5'].

${ }^{123}$ Connolly, Divided kingdom, 210.
} 
which 'mutually incompatible arguments succeed one another in an elaborate series of fall back positions' ${ }^{124}$ Once again this view seems incomplete. At any rate, the incompatibility so obvious to Connolly was not evident to contemporary defenders of the Westminster parliament. Atwood worried that the Case of Ireland set out 'many glittering Arguments' while Clement acknowledged that the book contained 'a Popular Argument, and is artfully written'. ${ }^{125}$

The apparent colour-blindness revealed in Molyneux's discussion of the ancient Irish is actually the key to appreciating that his intellectual world differed from our own, and possessed its own internal logic. Irish historians have generally followed Simms in supposing that the most important feature of Molyneux's work was his 'identification with the Irish past'. ${ }^{126}$ In fact, the Case of Ireland attests to the increasingly anglocentric orientation of Irish political discourse. Molyneux was claiming that the same principles employed against Stuart absolutism at the time of the Exclusion Crisis could equally be applied against Westminster's interference in Irish political affairs. Indeed he risked offending his metropolitan audience, as we have seen, by putting this argument in its inverse form: 'England may be said much more properly to be Conquer'd by William the First, than Ireland by Henry the Second' ${ }^{127}$ The ideological imperative for Molyneux was

\footnotetext{
${ }^{124}$ S. J. Connolly, 'Precedent and principle: the patriots and their critics', in idem (ed.), Political ideas in eighteenth-century Ireland (Dublin, 2000), 137.

${ }^{125}$ Atwood, Dependency of Ireland, 6; Clement, Answer to Molyneux, [A7].

${ }^{126}$ J. G. Simms, 'The establishment of Protestant ascendancy, 1691-1714', in T. W. Moody, and W. E. Vaughan (eds.), A new history of Ireland, vol. IV: Eighteenth-century Ireland 1690-1800 (Oxford, 1986), 5.

${ }^{127}$ Case of Ireland, 14.
} 
simply to prove by legal precedent that the foundations of the polity lay in consensual agreements rather than force.

The unspoken assumption was that the political class of Williamite Ireland (like their English counterparts) were bound by the decisions of their ancestors. But for these purposes ancestry was envisaged in terms of institutional structures rather than ethnic descent. In England William Atwood had taken an analogous position, denying not only that the Saxons had been conquered by the Normans, but that the Britons had been conquered by the Saxons. There was nothing peculiarly Irish about the incompatible arguments noted by Connolly: those whigs who believed that England possessed a Gothic constitution, brought from the German forests by their Saxon ancestors, nevertheless identified embryonic parliaments in the assemblies of the ancient Britons. ${ }^{128}$ The writings of Molyneux and Atwood were governed by rules, procedures and assumptions that differed from our own in ways that are sometimes difficult to reimagine. The questions they addressed were not questions about identity, or about national self-determination, or how 'the people of Ireland' should be defined; such ethnic and democratic preoccupations had yet to displace the principle of constitutional prescription which conferred legitimacy on the representative assemblies of the early modern period.

14,324 words

${ }^{128}$ Kidd, British identities before nationalism, 90. 